\title{
Cultural Practices and Mechanical Weed Control for the Management of a Low-Diversity Weed Community in Spinach
}

\author{
Ioannis Gazoulis ${ }^{1, *(D)}$, Panagiotis Kanatas ${ }^{2}(\mathbb{D})$ and Nikolaos Antonopoulos ${ }^{1}$ \\ 1 Laboratory of Agronomy, Agricultural University of Athens, 11855 Athens, Greece; \\ nikolasantwno@gmail.com \\ 2 Department of Crop Science, University of Patras, 30200 Messolonghi, Greece; pakanatas@gmail.com \\ * Correspondence: giangazoulis@gmail.com
}

Citation: Gazoulis, I.; Kanatas, P.; Antonopoulos, N. Cultural Practices and Mechanical Weed Control for the Management of a Low-Diversity Weed Community in Spinach. Diversity 2021, 13, 616. https:// doi.org/10.3390/d13120616

Academic Editor: Panayiotis Dimitrakopoulos

Received: 19 October 2021

Accepted: 23 November 2021

Published: 25 November 2021

Publisher's Note: MDPI stays neutral with regard to jurisdictional claims in published maps and institutional affiliations.

Copyright: (c) 2021 by the authors. Licensee MDPI, Basel, Switzerland. This article is an open access article distributed under the terms and conditions of the Creative Commons Attribution (CC BY) license (https:// creativecommons.org/licenses/by/ $4.0 /)$.

\begin{abstract}
Low-diversity weed communities are dominated by few species that are highly competitive to crops. The management of such weed communities should rely upon sustainable cultural and nonchemical practices, especially in crops such as spinach (Spinacia oleracea L.), where very few herbicides are available. A two-year field trial (2020 and 2021) was conducted to evaluate different fertilization practices (broadcast and banded), intra-row spacings $(15 \mathrm{~cm}, 11 \mathrm{~cm}, 7 \mathrm{~cm})$, and mechanical weed control treatments (untreated, one treatment, two treatments) for the management of a low-diversity weed community in spinach. Weed competition severely affected spinach commercial biomass $\left(\mathrm{R}^{2}=0.845\right)$. Compared to broadcast fertilization, banded fertilization reduced weed biomass and improved spinach yield and nitrogen use efficiency. Narrow intra-row spacing $(7-\mathrm{cm})$ reduced weed biomass by 28 and $45 \%$ compared to intra-row spacings of $11-\mathrm{cm}$ and $15-\mathrm{cm}$, respectively. Two mechanical weed control treatments resulted in $49 \%$ lower weed biomass compared to a single treatment. Commercial biomass increased with decreasing intra-row spacing $\left(R^{2}=0.881\right)$ and increasing the number of mechanical treatments $\left(R^{2}=0.911\right)$. More cultural and non-chemical practices should be evaluated for weed management in spinach, especially at sites infested with low-diversity weed communities.
\end{abstract}

Keywords: Setaria viridis (L.) P.Beauv.; Chenopodium album L.; banded fertilization; intra-row spacing; cage weeder; commercial biomass; nitrogen use efficiency

\section{Introduction}

Spinach (Spinacia oleracea L.; $2 n=2 x=12$ ) belongs to the botanical family Amaranthaceae and is considered one of the most important leafy vegetables consumed in all continents of the world [1]. In Europe, spinach production reached about 700 thousand tonnes, harvested on about 41 thousand hectares in 2019 [2]. It is a valuable food source for human nutrition as its leaves are rich in minerals, vitamins, and other molecules with antioxidant properties and phenolic compounds [3]. Mature leaves can be consumed fresh or stored frozen after cooking in boiling water; cultivation can also be directed towards the production of processed spinach or fresh-cut baby leaves [4-6]. The crop can be grown both in the greenhouse and under field conditions as a cool-season leafy vegetable [7]. However, there are hybrids and cultivars that are resistant to bolting, higher temperatures, and longer photoperiods and are a viable option for summer cultivation [8].

Weeds are an important obstacle to spinach productivity, as they reduce its commercial biomass and affect the quality of the harvested product [9-11]. The impact of weed competition on spinach yield is likely to be higher in fields infested with low-diversity weed communities. Such weed communities are dominated by a small number of weed species that are highly competitive and well adapted to the soil and climatic conditions of a given agricultural area [12-14]. Storkey and Neve [13] recently emphasized that as the number of species in a given weed community decreases, crop yield losses increase. Furthermore, herbicides are not a sustainable weed control option in agricultural areas 
with low weed diversity because their use increases the risk of selection of herbicideresistant weed populations [15]. Therefore, weed management in such areas should first rely upon sustainable cultural practices and non-chemical weed control methods. However, all alternative methods should aim to contribute to the restoration of weed flora composition [13]. Promoting weed species diversity should be regarded as a central issue in the development of sustainable weed management systems in agriculture [16]. This should be the target, rather than completely eliminating certain weed species from a given agricultural area and creating conditions for the invasions of other weed species that may also become dominant and highly competitive.

In any case, weed control is challenging in spinach fields since very few herbicides are available for use in this crop [17]. During past years, lenacil was the dominant herbicide for selective weed control in several spinach-producing countries in Europe [18-20]. However, it is very likely to be withdrawn from the market in European Union (EU) after the end of 2021 due to concerns for its environmental fate and impact on human health and non-target organisms [21,22]. In light of this situation, there are serious concerns among spinach growers in the EU regarding the available weed control options in the near future. Phenmedipham, a photosystem II (PS II) inhibitor, is the only option for the selective control of broadleaf weeds $[23,24]$. For the selective control of grass weeds, available herbicides are limited to acetyl-CoA-carboxylase (ACCase) inhibitors (i.e., cycloxydim, quizalofopp-ethyl, and propaquizafop) $[18,20]$. There is much evidence that overreliance on these herbicides will lead to the rapid evolution of herbicide-resistant weed populations [25]. As a result, there is an urgent need to evaluate alternative non-chemical weed management practices to develop sustainable weed management strategies in spinach fields [26].

Increasing the populations of crop plants in the row is an effective strategy for suppressing weeds and achieving higher yields [27]. De Cauwer et al. [9] found that narrow intra-row spacings reduced weed biomass and increased total and commercial spinach biomass. Similar reports indicated that the use of increased plant populations within the row can improve the competitiveness of even low-competitive crops with slow early growth rates [28,29]. In addition, such practices can be combined with mechanical weed control treatments between crop rows to further suppress weeds $[9,28-30]$. The study by De Cauwer et al. [9] provided evidence on the potential of such practices for weed suppression in spinach in Central Europe. However, there are no recent relevant studies conducted on this crop in the soil and climatic conditions of the Mediterranean region. As for mechanical weed control, spring-tine harrows, split-hoes, and finger-weeders provide a sufficient level of weed control between crop rows and are safe for spinach plants grown at 20-30 $\mathrm{cm}$ row spacing $[9,31,32]$. Cage weeders are another option since they are very effective and completely safe for leafy vegetables even in early growth stages. When this kind of machinery is used, the first cage loosens the soil and the second one pulverizes it, uprooting young weed seedlings [33]. Although they are very promising for weed control in leafy vegetables, no studies have recently evaluated their performance in spinach along with crop establishment at narrow intra-row spacings.

Except for the above-mentioned practices, fertilization management is another factor that can be used for weed management purposes. Although the conventional fertilization practice in spinach is to broadcast the fertilizer at seedbed preparation, it should be remembered that weeds have a more aggressive nutrient uptake compared to crops and tend to be more competitive at higher nutrient levels [34]. Thus, broadcast fertilization should be avoided in fields with heavy weed infestation as it favors weed growth over crop growth [35]. In contrast to broadcast fertilization, banding fertilizers under the crop rows provide crops a competitive advantage over weeds by giving cultivated plants optimal access to nutrients [26]. In leafy vegetables, there is evidence that banded fertilization promotes crop growth over weed growth [36,37]. Moreover, this practice is beneficial from an agro-ecological point of view as it reduces fertilizer inputs in agriculture [38]. Considering all these reasons, banded fertilization should be considered as an alternative for fertilizing spinach and other leafy vegetables [26]. However, no studies have assessed 
the potential of banded fertilization for weed management purposes in spinach. There are also no studies available in this crop evaluating banded fertilization along with the factors of intra-row spacing and mechanical weed control in a single field trial.

The objective of the present study was to evaluate different fertilization practices (broadcast and banded), spinach intra-row spacings, and the number of mechanical weed control treatments for weed management in spinach. The experiment was conducted at a site infested with a low-diversity weed community dominated by two specific species. The effects of all experimental factors on spinach yield performance and nitrogen use efficiency are also presented.

\section{Materials and Methods}

\subsection{Site Description}

A two-year field trial was conducted in the prefecture of Agrinion in western Greece during the 2019-2020 and 2020-2021 growing seasons. The experimental site was located at $21^{\circ} 25^{\prime} 18^{\prime \prime}$ east latitude and the north longitude was $38^{\circ} 32^{\prime} 10^{\prime \prime}$. To collect precise location data, the World Geodetic System 1984 (WGS84) was the geographic coordinate system used. Spinach was the crop studied, and in particular, the hybrid 'Strongher F1' was selected as plant material (Agrogen S.A., Athens, Koropi, Greece). This hybrid is suitable for spring cultivation in these areas and was also selected for its rapid and upright growth and resistance to 11 races of downy mildew (Peronospora farinosa f. sp. spinaciae Byford). The crop was grown in the field from April to June in both 2020 and 2021. Regarding climatic conditions during the experimental period, similar air temperature data were collected in the two growing seasons, while monthly precipitation in April and May was 29.6 and $46 \mathrm{~mm}$ higher, respectively, in 2020 than in 2021 (Table 1).

Table 1. Mean, mean maximum, and mean minimum monthly temperature $\left({ }^{\circ} \mathrm{C}\right)$ and total monthly precipitation $(\mathrm{mm})$ values observed in the experimental area.

\begin{tabular}{ccccccccc}
\hline & \multicolumn{9}{c}{ Weather Parameter } \\
\cline { 2 - 9 } Month & $\begin{array}{c}c \\
\text { Mean }\end{array}$ & \multicolumn{1}{c}{$\begin{array}{c}\text { Mean Maximum } \\
\text { Temperature }\left({ }^{\circ} \mathbf{C}\right)\end{array}$} & $\begin{array}{c}\text { Temperature }\left({ }^{\circ} \mathbf{C}\right) \\
\text { Temperature }\left({ }^{\circ} \mathbf{C}\right)\end{array}$ & $\begin{array}{c}\text { Total } \\
\text { Precipitation (mm) }\end{array}$ \\
\cline { 2 - 10 } & $\mathbf{2 0 2 0}$ & $\mathbf{2 0 2 1}$ & $\mathbf{2 0 2 0}$ & $\mathbf{2 0 2 1}$ & $\mathbf{2 0 2 0}$ & $\mathbf{2 0 2 1}$ & $\mathbf{2 0 2 0}$ & $\mathbf{2 0 2 1}$ \\
\hline March & 12.7 & 11.2 & 18.1 & 16.1 & 7.3 & 6.3 & 53.0 & 69.8 \\
April & 14.8 & 15.1 & 20.7 & 20.7 & 8.9 & 9.5 & 39.8 & 10.2 \\
May & 21.0 & 21.2 & 27.3 & 27.4 & 14.7 & 15.0 & 48.8 & 2.8 \\
June & 23.2 & 25.0 & 29.1 & 31.6 & 17.3 & 18.4 & 25.6 & 20.6 \\
\hline
\end{tabular}

The soil type was clay loam (CL) with the following characteristics (0 to $30 \mathrm{~cm}): 28.1 \%$ clay, $25.9 \%$ silt, and $46.7 \%$ sand with a pH of 7.3 and an organic matter content of $1.0 \%$. Spinach and swiss chard (Beta vulgaris L. subsp. cicla) were the crops grown on the soil of the experimental field in the previous growing seasons. At this site, a low-diversity weed community was established in which Setaria viridis (L.) P.Beauv. and Chenopodium album L. were the dominant weed species. These species were very persistent throughout the experimental period and accounted for more than $95 \%$ of the total weed biomass in both 2020 and 2021 (data not shown). Other weed species such as Portulaca oleracea L., Tribulus terrestris L., and Polygonum aviculare L. were also present but at very low densities (data not shown).

\subsection{Experimental Setup}

For seedbed preparation, the soil was initially plowed to a depth of $35 \mathrm{~cm}$ on 9 April 2020 and 10 April 2021. Soil plowing was followed by disc harrowing and spring-tooth harrowing to break up soil clods. A 'Krosker' cultipacker (Agricultural Machinery-S. Milonas 1983 O.E., Thessaloniki, Adendro, Greece) was also run on the field as a final operation to prepare a firm seedbed. Spinach was sown on 18 April 2020 and 20 April 
2021 using a manual precision seed drill 'SJ Expert' suitable for sowing leafy vegetables (Sepeba Ibra, Les Grès, Saint Mar-tin du Fouilloux, France). The crop was sown in rows that were spaced $30 \mathrm{~cm}$ apart, at a sowing rate of $25 \mathrm{~kg}$ seed ha ${ }^{-1}$ and a sowing depth of $2.5 \mathrm{~cm}$. After sowing, the soil was cultipacked again to achieve good seed-soil contact, and an initial irrigation was carried out with sprinklers [39].

The experiment was conducted in a three-factorial (split-split-plot arrangement) randomized complete block design (RCBD) with four replications (blocks). Two fertilization practices were assigned to the main plots, three spinach intra-row spacings were assigned to the subplots, and three different mechanical weed control treatments were assigned to the sub-subplots. Each sub-subplot included ten rows of spinach and was $3 \mathrm{~m}$ wide and $5 \mathrm{~m}$ long, giving a total sub-subplot size of $15 \mathrm{~m}^{2}$. The subplots were $12 \mathrm{~m}$ wide and $15 \mathrm{~m}$ long giving a total subplot size of $180 \mathrm{~m}^{2}$, while the main plots were $36 \mathrm{~m}$ wide and $15 \mathrm{~m}$ long giving a total main plot size of $540 \mathrm{~m}^{2}$. The experimental layout included 72 experimental units (sub-subplots), and the total acreage of spinach in the experimental area was $1.080 \mathrm{~m}^{2}$. Borders of $0.60,1.2$, and $2.4 \mathrm{~m}$ were also kept between adjacent sub-subplots, subplots, and main plots, respectively, in both 2020 and 2021. In 2021, new plots were established in an adjacent but different area of the same site to avoid any residual effects of the fertilizer on the studied parameters and to actually repeat the experiment in time.

The different fertilization regimes included the broadcast and banded applications of a synthetic complete fertilizer (N-P-K: 12-12-12 $+35 \mathrm{SO}_{3}+10 \%$ organic matter; Organofert ${ }^{\circledR}$, Hellagrolip S.A., Athens, Paleo Faliro, Greece). For broadcast application, the fertilizer was applied after the initial tillage operation to supply the soil with $120 \mathrm{~kg} \mathrm{~N} \mathrm{ha}^{-1}, 120 \mathrm{~kg}$ $\mathrm{P}_{2} \mathrm{O}_{5}$, and $120 \mathrm{~kg} \mathrm{~K}_{2} \mathrm{O} \mathrm{ha}^{-1}$. For banded application, the fertilizer was placed in bands at $10 \mathrm{~cm}$ depth below crop rows to supply the soil with $66 \mathrm{~kg} \mathrm{~N} \mathrm{ha}^{-1}, 66 \mathrm{~kg} \mathrm{P}_{2} \mathrm{O}_{5} \mathrm{ha}^{-1}$, and $66 \mathrm{~kg} \mathrm{~K}_{2} \mathrm{O} \mathrm{ha}^{-1}$. Spinach emerged on 25 April 2020 and 26 April 2021, and the stand was hand-thinned (on 3 May in both years) when the plants had reached the 3-leaf growth stage (BBCH: 13). Thinning was done in such a way that we obtained three different intra-row spacings, namely $15 \mathrm{~cm}, 11 \mathrm{~cm}$, and $7 \mathrm{~cm}$.

As for mechanical weed control treatments, weeds were mechanically controlled between crop rows with a cage weeder (K.U.L.T. Kress Umweltschonende Landtechnik $\mathrm{GmbH}$, Vaihingen an der Enz, Germany/E. Sanidas-Agricultural-Gardening Equipment \& Tools, Goumenissa, Kilkis, Greece). All mechanical operations were conducted at a working speed of $3 \mathrm{~km} \mathrm{~h}^{-1}$ and a working depth of $3 \mathrm{~cm}$. An untreated control was maintained where weeds remained uncontrolled, while the first weed control treatment included a single inter-row mechanical weeding at the 4-leaf growth stage of spinach (BBCH: 14). The second weed control treatment included two inter-row mechanical weedings at the 4- and 6-leaf growth stages of spinach (BBCH: 14-16). In both years, the dates for the first and second mechanical treatment were 13 and 20 May, when most weeds were between the 'white' or 'thread' (emergence) and 2-leaf growth stages (BBCH: 09-12).

As for other crop management practices applied during both growing seasons, irrigations were carried out weekly with sprinklers to supply the crop with $25 \mathrm{~mm}$ of water per week, depending on the rainfall events that occurred. To adequately meet the nitrogen requirements of spinach, a foliar application of completely water-soluble urea (N-P-K: 46-0-0; AGRI.FE.M. Ltd., Athens, Aspropirgos, Greece) was carried out 15 days after crop emergence. Urea was applied at a concentration of $1.5 \%(v / w)$ with a pressurized Gloria ${ }^{\circledR}$ 410 T sprayer (Gloria Haus \& Gartengeraete GMBH, Witten, Germany) calibrated to deliver $210 \mathrm{~L} \mathrm{ha}^{-1}$ of spray solution at a constant pressure of $400 \mathrm{kPa}$ through a brass hollow-cone nozzle (2 mm diameter; $80^{\circ}$ spray angle) to provide $69 \mathrm{~kg} \mathrm{~N} \mathrm{ha}^{-1}$ to the crop. Spinach anthranose [Colletotrichum dematium f. sp. spinaciae (Ellis \& Halsted) Arx] was controlled by two foliar pyraclostrobin (Signum ${ }^{\circledR}$ 26,7/6,7 WG, Basf Hellas S.A., Athens Greece) applications at $67 \mathrm{~g}$ ai ha ${ }^{-1}\left(400 \mathrm{~L} \mathrm{ha}^{-1}\right.$ spray solution; $275 \mathrm{kPa}$ pressure) at the 4- and 6-leaf growth stages of spinach (BBCH: 14-16). Sulfoxaflor (Closer ${ }^{\mathrm{TM}} 120 \mathrm{SC}$, Corteva Agriscience Hellas S.A., Athens, Greece) was also applied at $24 \mathrm{~g}$ ai ha ${ }^{-1}$ (200 $\mathrm{L} \mathrm{ha}^{-1}$ spray 
solution; $275 \mathrm{kPa}$ pressure) to control green peach aphid infections [Myzus persicae (Sulzer, 1776)] at the 9-leaf growth stage of spinach (BBCH: 19).

\subsection{Data Collection}

Four $0.25 \mathrm{~m}^{2}(0.5 \times 0.5 \mathrm{~m})$ metallic quadrats were placed in each sub-subplot the day after the last mechanical weeding, in areas with uniform weed flora and away from the margins. Each quadrat included two crop rows resulting in a total of 8, 10, and 16 spinach plants per quadrat at intra-row distances of $15 \mathrm{~cm}, 11 \mathrm{~cm}$, and $7 \mathrm{~cm}$, respectively. Weeds were harvested by clipping plants to a height of $2 \mathrm{~cm}$ with scissors, separating them by species, and placing them in numbered plastic bags. The first weed harvest was carried out in two quadrats, at approximately three weeks after the last mechanical weed control treatment and when the spinach stand was successfully established (29 May 2020 and 30 May 2021). The weed samples were then weighed to determine the fresh weed biomass per unit area using a ' $\mathrm{KF}-\mathrm{H} 2^{\prime}$ ' digital balance (Zenith S.A., Athens, Greece). The biomass of the two dominant weed species (i.e., S. viridis and C. album) was measured separately, while the total weed biomass was also measured. To do this, the biomass of other weeds that occurred at minor densities were included in the measurements of total weed biomass. Weed biomass was reassessed the day before spinach harvest (15 June in both 2020 and 2021) in the other two quadrats in each sub-subplot.

Spinach was harvested on 16 June in both years, when the plants had reached their typical leaf mass before the onset of shoot elongation (BBCH: 49). In each sub-subplot, the entire three middle rows of spinach were harvested to measure the total (fresh) spinach biomass per unit area. Harvest was done with scissors at a height of $5 \mathrm{~cm}$ to reduce the proportion of petioles in the harvested vegetation. Subsequently, the harvested vegetation was manually sorted into commercial (green leaves) and non-commercial spinach biomass (cotyledons, petiole parts separated from leaves, yellow leaves, etc.). Spinach waste, the proportion (\%) of non-marketable spinach biomass to total spinach biomass, and the proportion (\%) of total weed biomass to total spinach biomass were also assessed. In addition, nitrogen use efficiency (NUE) was estimated as the ratio of total spinach biomass to the total amount of nitrogen supplied to the crop.

\subsection{Statistical Analysis}

Data from each measurement were subjected to an initial 4-factor Analysis of Variance (ANOVA) conducted at $a=0.05$ significance level. Years, fertilization practices, intra-row spinach spacings, and mechanical weed control practices were considered as fixed effects while replications (blocks) were considered as random effects. The initial ANOVAs revealed that the effects of years on the studied parameters were not significant ( $p$-Value $\geq 0.05$ ). Therefore, combined data analyses were conducted over the two growing seasons (2020 and 2021) for each parameter. To run the model for each parameter, fertilization, intra-row spacing, and mechanical weed control were considered as fixed effects, while replications were considered random effects. For each factor, means were separated according to Fischer's LSD (Least Significance Difference) test at an $a=0.05$ significance level.

To express the relationships between (a) total weed biomass and the different intra-row spacings (b) total weed biomass and the number of mechanical weed control treatments, data fitted to the second order polynomial model (Equation (1)):

$$
y=a+b x+c x^{2}
$$

where $a$ is the intercept, $b$ and $c$ are constants, $y$ is the dependent variable representing total weed biomass, and $x$ is the dependent variable representing (a) intra-row spacing or (b) mechanical weed control treatments. The same model was used to express the relationships between (a) total/commercial spinach biomass (considered as the dependent variables $y$ ) and the different intra-row spacings (considered as the dependent variable $x$ ) and also between (b) total/commercial spinach biomass $(y)$ and the number of mechanical weed control treatments $(x)$. To express these relationships, data were pooled over all 
other experimental factors when intra-row spacing, or mechanical weed control was the dependent variable in each case. In addition, the relationship between total/commercial spinach biomass and total weed biomass was expressed according to the reciprocal linear model (Equation (2)):

$$
y=\frac{1}{a+b x}
$$

where $a$ is the intercept, $b$ is the slope of the regression line, $y$ is the dependent variable representing total/commercial spinach biomass, and $x$ is the independent variable representing total weed biomass. In all regression analyses where total weed biomass was used as the dependent or independent variable, data from the second evaluation of weed biomass were used. Statgraphics Centurion XVI (Statgraphics Technologies, Inc., P.O. Box 134, The Plains, VA 20198, USA) was the statistical package used for all data analyses.

\section{Results}

\subsection{Weed Biomass}

$S$. viridis biomass was affected by the different fertilization practices in the first $(p$-Value $\leq 0.01)$ and the second evaluation $(p$-Value $\leq 0.05) . C$. album biomass was not affected by the factor of fertilization $(p$-Value $\geq 0.05)$. In addition, significant were the effects of intra-row spacing and mechanical weed control on the biomass of both $S$. viridis and C. album ( $p$-Value $\leq 0.001$ ) and also on total weed biomass in both evaluations (Table 2).

Table 2. The effects of fertilization, intra-row spacing, and mechanical weed control on the biomass of Setaria viridis (L.) P.Beauv. and Chenopodium album L., and total weed biomass. For each parameter, $p$-Values are shown as derived from three-factor Analysis of Variance (ANOVA) $(a=0.05)$.

\begin{tabular}{|c|c|c|c|c|c|c|c|}
\hline \multirow{3}{*}{ Source } & \multirow{3}{*}{$\mathrm{Df}^{1}$} & \multicolumn{6}{|c|}{$p$-Value } \\
\hline & & \multicolumn{2}{|c|}{$\begin{array}{l}\text { S. viridis } \\
\text { Biomass }\end{array}$} & \multicolumn{2}{|c|}{$\begin{array}{l}\text { C. album } \\
\text { Biomass }\end{array}$} & \multicolumn{2}{|c|}{$\begin{array}{c}\text { Total Weed } \\
\text { Biomass }\end{array}$} \\
\hline & & Eval $^{2} 1$ & Eval 2 & Eval 1 & Eval 2 & Eval 1 & Eval 2 \\
\hline Fertilization (F) & 1 & $* 4$ & ** & 0.7824 & 0.7506 & * & * \\
\hline Error $^{3}$ (a) & 3 & & & & & & \\
\hline $\begin{array}{l}\text { Intra-Row Spacing } \\
\text { (IRS) }\end{array}$ & 2 & $* * *$ & $* * *$ & $* * *$ & $* * *$ & $* * *$ & $* * *$ \\
\hline $\mathrm{F} \times \mathrm{IRS}$ & 2 & 0.9945 & 0.9369 & 0.6569 & 0.5715 & 0.8732 & 0.8519 \\
\hline Error (b) & 12 & & & & & & \\
\hline $\begin{array}{c}\text { Mechanical Weed } \\
\text { Control (MWC) }\end{array}$ & 2 & $* * *$ & $* * *$ & $* * *$ & $* * *$ & $* * *$ & $* * *$ \\
\hline $\mathrm{F} \times \mathrm{WC}$ & 2 & 0.5870 & 0.2438 & 0.9723 & 0.9776 & 0.8794 & 0.8717 \\
\hline $\mathrm{IRS} \times \mathrm{WC}$ & 4 & 0.6166 & 0.5279 & 0.5493 & 0.4948 & 0.7835 & 0.8216 \\
\hline $\mathrm{F} \times \mathrm{IRS} \times \mathrm{MWC}$ & 4 & 0.8795 & 0.7829 & 0.9946 & 0.9955 & 0.9996 & 0.9989 \\
\hline Error $(\mathrm{c})$ & 36 & & & & & & \\
\hline Total & 71 & & & & & & \\
\hline
\end{tabular}

${ }^{1}$ Df; Degrees of freedom. ${ }^{2}$ Eval; Evaluation. ${ }^{3}$ Error (a); Block $\times$ F, Error (b); Block $\times$ IRS (F), Error (c); Block $\times$ MWC $(\mathrm{F} \times \mathrm{IRS}) .{ }^{* *}, * * * * * ; p$-Value $\leq 0.05,0.01$, and 0.001 , respectively.

Banded fertilizer application reduced S. viridis biomass by $15-19 \%$ compared to broadcast fertilizer application. The intra-row spacing of $11 \mathrm{~cm}$ resulted in $17-23 \%$ lower fresh weight for $S$. viridis compared to the intra-row spacing of $15 \mathrm{~cm}$. Selecting the intra-row spacing of $7 \mathrm{~cm}$ caused up to $25 \%$ reductions to the biomass of this species in comparison to $11 \mathrm{~cm}$. As for mechanical weed control, one treatment reduced $S$. viridis fresh weight by more than $60 \%$ in both evaluations compared to the untreated control. In sub-subplots treated mechanically two times, $S$. viridis biomass was $47 \%$ lower than in plots treated mechanically one time (Table 3). 
Table 3. Setaria viridis (L.) P.Beauv. and Chenopodium album L. biomass $\left(\mathrm{g} \mathrm{m}^{-2}\right)$ data obtained for each experimental factor. Total weed biomass data $\left(\mathrm{g} \mathrm{m}^{-2}\right)$ are also included. Means were separated according to Fischer's Least Significance Difference (LSD) test $(a=0.05)$.

\begin{tabular}{|c|c|c|c|c|c|c|}
\hline \multirow{3}{*}{ Factors } & \multicolumn{6}{|c|}{ Weed Biomass } \\
\hline & \multicolumn{2}{|c|}{$\begin{array}{l}\text { S. viridis } \\
\text { Biomass } \\
\left(\mathrm{g} \mathrm{m}^{-2}\right)\end{array}$} & \multicolumn{2}{|c|}{$\begin{array}{l}\text { C. album } \\
\text { Biomass } \\
\left(\mathrm{g} \mathrm{m}^{-2}\right)\end{array}$} & \multicolumn{2}{|c|}{$\begin{array}{c}\text { Total Weed } \\
\text { Biomass } \\
\left(\mathrm{g} \mathrm{m}^{-2}\right)\end{array}$} \\
\hline & Eval $^{1} 1$ & Eval 2 & Eval 1 & Eval 2 & Eval 1 & Eval 2 \\
\hline \multicolumn{7}{|l|}{ Fertilization $(\mathrm{F})$} \\
\hline Broadcast & $97.9 \mathrm{a}^{2}$ & $164.9 \mathrm{a}$ & $62.0 \mathrm{a}$ & $109.3 \mathrm{a}$ & $164.2 \mathrm{a}$ & $283.4 \mathrm{a}$ \\
\hline Banded & $82.9 \mathrm{~b}$ & $133.6 \mathrm{~b}$ & $61.1 \mathrm{a}$ & $105.2 \mathrm{a}$ & $146.9 \mathrm{~b}$ & $246.7 \mathrm{~b}$ \\
\hline $\mathrm{LSD}_{\mathrm{F}}$ & 8.58 & 13.63 & 10.24 & 18.45 & 16.23 & 29.40 \\
\hline \multicolumn{7}{|l|}{ Intra-Row Spacing (IRS) } \\
\hline $15 \mathrm{~cm}$ & $114.3 \mathrm{a}$ & $182.2 \mathrm{a}$ & $85.5 \mathrm{a}$ & $150.7 \mathrm{a}$ & $204.1 \mathrm{a}$ & $343.5 \mathrm{a}$ \\
\hline $11 \mathrm{~cm}$ & $87.8 \mathrm{~b}$ & $151.1 \mathrm{~b}$ & $60.9 \mathrm{~b}$ & $103.9 \mathrm{~b}$ & $151.9 \mathrm{~b}$ & $262.7 \mathrm{~b}$ \\
\hline $7 \mathrm{~cm}$ & $69.2 \mathrm{c}$ & $114.5 \mathrm{c}$ & $38.3 \mathrm{c}$ & $67.1 \mathrm{c}$ & $110.6 \mathrm{c}$ & $188.9 \mathrm{c}$ \\
\hline LSD IRS & 15.01 & 24.87 & 12.35 & 21.78 & 26.71 & 47.94 \\
\hline \multicolumn{7}{|c|}{ Mechanical Weed Control (MWC) } \\
\hline Untreated (Control) & $171.9 \mathrm{a}$ & $279.7 \mathrm{a}$ & $105.2 \mathrm{a}$ & $180.6 \mathrm{a}$ & $282.2 \mathrm{a}$ & $472.8 \mathrm{a}$ \\
\hline One Treatment $(1 \times)$ & $65.4 \mathrm{~b}$ & $110.4 \mathrm{~b}$ & $53.6 \mathrm{~b}$ & $95.3 \mathrm{~b}$ & $122.1 \mathrm{~b}$ & $213.0 \mathrm{~b}$ \\
\hline Two Treatments $(2 \times)$ & $34.6 \mathrm{c}$ & $57.7 \mathrm{c}$ & $25.9 \mathrm{c}$ & $45.9 \mathrm{c}$ & $62.4 \mathrm{c}$ & $109.3 \mathrm{c}$ \\
\hline LSD $_{\text {MWC }}$ & 12.94 & 21.54 & 24.22 & 42.32 & 33.62 & 60.89 \\
\hline
\end{tabular}

${ }^{1}$ Eval; Evaluation. ${ }^{2}$ Different lowercase letters in the same column indicate significant differences between means of each factor.

The intra-row spacing of $11 \mathrm{~cm}$ reduced C. album fresh weight by 29 and 31\%, in the first and the second evaluation, respectively, compared to the intra-row spacing of $15 \mathrm{~cm}$. Spinach establishment with $7 \mathrm{~cm}$ intra-row spacing resulted in the lowest values of C. album biomass in both evaluations. Regarding mechanical weed control, C. album fresh weight decreased by $47-49 \%$ in sub-subplots receiving one treatment in comparison to untreated control sub-subplots. Two mechanical treatments resulted in the lowest biomass production in this species.

In the first and the second evaluation, total weed biomass was 11 and $13 \%$ lower, respectively, in the main plots where fertilizer was applied in bands than in the main plots receiving broadcast fertilization. The results of the first evaluation revealed that narrow intra-row spacing resulted in the lowest values of total weed biomass. Total weed biomass was highest under $15 \mathrm{~cm}$ intra-row spacing while intermediate values corresponded to $11 \mathrm{~cm}$. Moreover, weed fresh weight per unit area was lowest in sub-subplots receiving two mechanical weed control treatments and highest in untreated sub-subplots. Intermediate values corresponded to sub-subplots receiving a single treatment. The results of the second evaluation are consistent with those of the first evaluation. There were strong relationships between total weed biomass and either intra-row spacing or mechanical weed control (Figure 1).

The expression of total weed biomass as a function of intra-row spacing was performed according to the second order polynomial model: $T W B=76.837+(14.4706$ $\times I R S)+\left(0.220427 \times I R S^{2}\right)$ where TWB; total weed biomass, IRS; intra-row, $\mathrm{n}=12$, $p$-Value Model $\leq 0.001, \mathrm{R}^{2}=0.843$, root mean square error $(\mathrm{RMSE})=31.425$, and mean absolute error $(\mathrm{MAE})=19.286$. This relationship indicated that $84.3 \%$ of the variation observed in total weed biomass was due to the different intra-row spacings of spinach (Figure 1a). Pooled over all other experimental factors, weed biomass decreased by $24 \%$ in subplots where spinach was thinned to $11 \mathrm{~cm}$ intra-row spacing instead of $15 \mathrm{~cm}$. In addition, the narrowest intra-row spacing $(7 \mathrm{~cm})$ resulted in 28 and $45 \%$ lower weed fresh weight per unit area compared to the wider intra-row spacings of 11 and $15 \mathrm{~cm}$, respectively. 

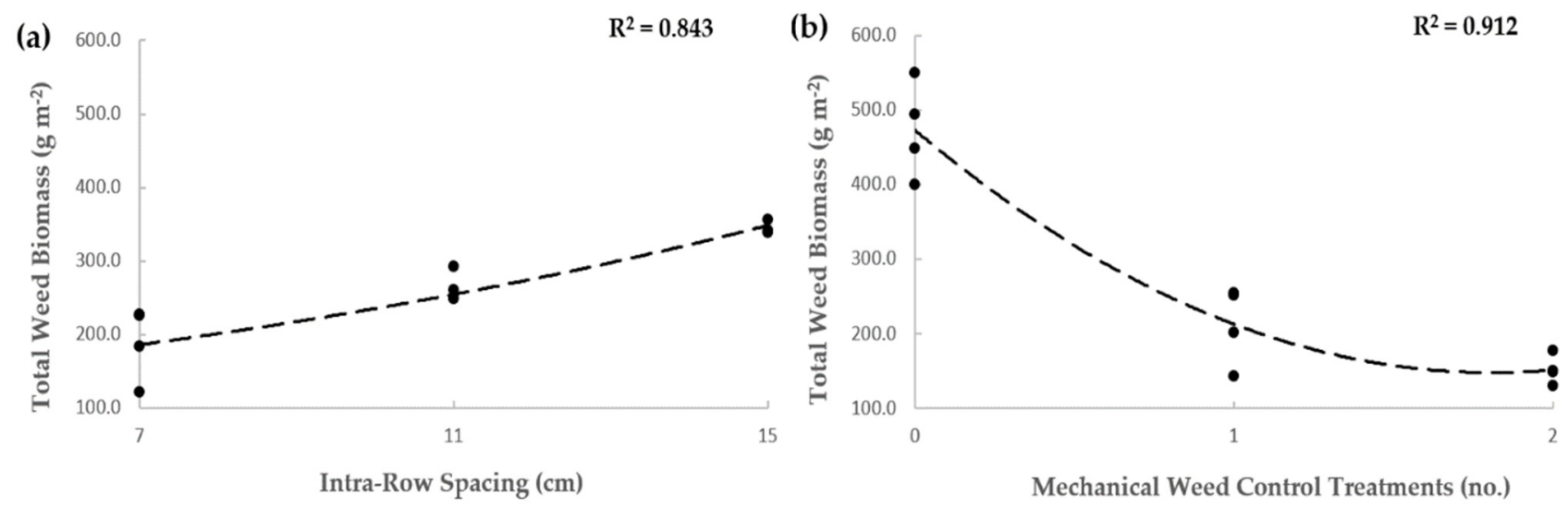

Figure 1. (a) The relationship between total weed biomass $\left(\mathrm{g} \mathrm{m}^{-2}\right)$ and intra-row spacing $(\mathrm{cm})$. (b) The relationship between total weed biomass $\left(\mathrm{g} \mathrm{m}^{-2}\right)$ and the number of mechanical weed control treatments.

Total weed biomass was also expressed as a function of the number of mechanical weed control treatments according to the second order polynomial model: $T W B=$ $472.851-(359.11 \times M W C)+\left(99.234 \times M W C^{2}\right)$ where TWB; total weed biomass, $M W C$; mechanical weed control, $\mathrm{n}=12, p$-Value Model $\leq 0.001, \mathrm{R}^{2}=0.912$, root mean square error $($ RMSE $)=48.748$, and mean absolute error $(\mathrm{MAE})=33.745$. This relationship indicated that $91.2 \%$ of the variation observed in total weed biomass was due to the number of weed control treatments (Figure $1 \mathrm{~b}$ ). Pooled over all other experimental factors, total weed biomass was $55 \%$ lower in sub-subplots treated mechanically once than in untreated sub-subplots. Moreover, two mechanical treatments resulted in 49 and $77 \%$ lower weed biomass compared to one treatment and the untreated control, respectively.

\subsection{Spinach Biomass}

Fertilization influenced both total and commercial spinach biomass ( $p$-Value $\leq 0.01$ ). The proportions of spinach waste and weed biomass to total spinach biomass were also significantly affected by the different fertilization practices ( $p$-Value $\leq 0.05)$. Similar results were obtained for nitrogen use efficiency ( $p$-Value $\leq 0.001$ ). Significant were the effects of intra-row spacing on total and commercial spinach biomass ( $p$-Value $\leq 0.001)$. The same was observed for the proportion of weed biomass in total spinach biomass and also for nitrogen use efficiency ( $p$-Value $\leq 0.001)$. The proportion of weed biomass in total spinach biomass was also affected by the interaction between intra-row spacing mechanical weed control. Spinach waste proportion in total spinach biomass was another factor affected by the factor of intra-row spacing ( $p$-Value $\leq 0.05)$. The factor of mechanical weed control exerted a great influence on all studied parameters (Table 4).

Before explaining the results of mean separation for each factor, it should be noted that there was a strong relationship between total spinach and total weed biomass as well as between commercial spinach and total weed biomass (Figure 2).

There was a strong negative correlation between total spinach biomass and total weed biomass described by the reciprocal linear model: TSB $=1 /[0.0284963+(0.0000474821 \times$ TWB $)]$ where TSB; total spinach biomass, TWB; total weed biomass, $\mathrm{n}=72, p$-Value Model $\leq 0.001$, $R^{2}=0.836$, root mean square error $(\mathrm{RMSE})=0.00397871$, and mean absolute error $(\mathrm{MAE})=0.00305125$. Commercial spinach biomass was also negatively correlated with total weed biomass as well: $C S B=1 /[(0.0337985+0.0000658688 \times T W B)]$ where $C S B$; commercial spinach biomass, TWB; total weed biomass, $\mathrm{n}=72, p$-Value Model $\leq 0.001, \mathrm{R}^{2}=0.845$, root mean square error $(\mathrm{RMSE})=0.00533835$, and mean absolute error $(\mathrm{MAE})=0.00413492$. 
Table 4. The effects of fertilization, intra-row spacing, and mechanical weed control on total spinach biomass, commercial spinach biomass, spinach waste proportion, weed biomass proportion, and nitrogen use efficiency. For each parameter, $p$-Values of are presented as derived from three-factor Analysis of Variance (ANOVA) performed $(a=0.05)$.

\begin{tabular}{|c|c|c|c|c|c|c|}
\hline \multirow{3}{*}{ Source } & \multirow[b]{3}{*}{$\mathrm{Df}^{1}$} & \multicolumn{5}{|c|}{ Spinach Biomass } \\
\hline & & \multicolumn{5}{|c|}{$p$-Value } \\
\hline & & $\begin{array}{c}\text { Total } \\
\text { Spinach } \\
\text { Biomass }\end{array}$ & $\begin{array}{c}\text { Commercial } \\
\text { Spinach } \\
\text { Biomass }\end{array}$ & $\begin{array}{l}\text { Spinach Waste } \\
\text { Proportion }\end{array}$ & $\begin{array}{c}\text { Weed } \\
\text { Biomass } \\
\text { Proportion }\end{array}$ & $\begin{array}{c}\text { Nitrogen } \\
\text { Use } \\
\text { Efficiency }\end{array}$ \\
\hline Fertilization $(\mathrm{F})$ & 1 & $* * 3$ & ** & * & * & *** \\
\hline Error $^{2}$ (a) & 3 & & & & & \\
\hline Intra-Row Spacing (IRS) & 2 & $* * *$ & $* * *$ & * & $* * *$ & *** \\
\hline $\mathrm{F} \times \mathrm{IRS}$ & 2 & 0.8985 & 0.9598 & 0.8510 & 0.7064 & 0.1362 \\
\hline Error (b) & 12 & & & & & \\
\hline Mechanical Weed Control (MWC) & 2 & $* * *$ & $* * *$ & $* * *$ & $* * *$ & $* * *$ \\
\hline $\mathrm{F} \times \mathrm{MWC}$ & 2 & 0.8704 & 0.7157 & 0.7317 & 0.4892 & 0.1495 \\
\hline $\mathrm{IRS} \times \mathrm{MWC}$ & 4 & 0.9944 & 0.9402 & 0.4851 & * & 0.8715 \\
\hline $\mathrm{F} \times \mathrm{IRS} \times \mathrm{MWC}$ & 4 & 0.9996 & 0.9998 & 0.7078 & 0.9732 & 0.9967 \\
\hline Error (c) & 36 & & & & & \\
\hline Total & 71 & & & & & \\
\hline
\end{tabular}

${ }^{1}$ Df; Degrees of freedom. ${ }^{2}$ Error (a); Block $\times$ F, Error (b); Block $\times$ IRS (F), Error (c); Block $\times$ MWC $\left(\mathrm{F} \times\right.$ IRS). ${ }^{3 *},{ }^{* *},{ }^{* * *} ; p$-Value $\leq 0.05,0.01$, and 0.001 , respectively.

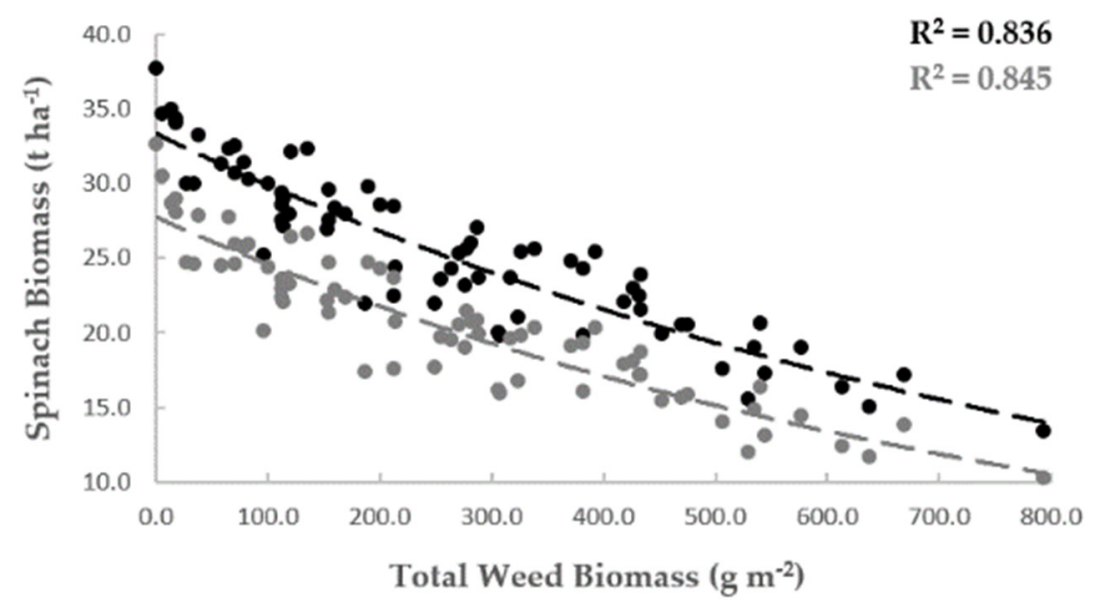

Figure 2. Black: the relationship between total spinach biomass $\left(\mathrm{t} \mathrm{ha}^{-1}\right)$ and total weed biomass $\left(\mathrm{g} \mathrm{m}^{-2}\right)$. Grey: the relationship between commercial spinach biomass $\left(\mathrm{t} \mathrm{ha}^{-1}\right)$ and total weed biomass $\left(\mathrm{g} \mathrm{m}^{-2}\right)$.

As for the effects of fertilization on crop productivity, banded fertilization increased total spinach biomass and commercial spinach biomass by 11 and $12 \%$, respectively, compared to broadcast fertilization. Moreover, the proportions of non-commercial spinach biomass and weed biomass in total spinach biomass were significantly lower in the main plots where fertilizer was applied in bands than the values recorded in the main plots where broadcast fertilization was carried out. This agronomic practice was also beneficial for the crop since it improved its nitrogen use efficiency by $38 \%$ when applied instead of the conventional fertilization practice (Table 5). 
Table 5. Total spinach biomass $\left(\mathrm{t} \mathrm{ha}^{-1}\right)$, commercial spinach biomass $\left(\mathrm{t} \mathrm{ha} \mathrm{a}^{-1}\right)$, spinach waste proportion $(\%)$, weed biomass proportion (\%), and nitrogen use efficiency $\left(\mathrm{kg} \mathrm{kg}^{-1}\right)$ data obtained for each experimental factor. Means were separated according to Fischer's Least Significance Difference (LSD) test $(a=0.05)$.

\begin{tabular}{|c|c|c|c|c|c|}
\hline \multirow[b]{2}{*}{ Factors } & \multicolumn{5}{|c|}{ Spinach Biomass } \\
\hline & $\begin{array}{l}\text { Total } \\
\text { Spinach } \\
\text { Biomass } \\
\left(t \text { ha }^{-1}\right)\end{array}$ & $\begin{array}{l}\text { Commercial } \\
\text { Spinach } \\
\text { Biomass } \\
\left(\mathbf{t} \mathbf{h a}^{-1}\right)\end{array}$ & $\begin{array}{c}\text { Spinach Waste } \\
\text { Proportion } \\
(\%)\end{array}$ & $\begin{array}{c}\text { Weed } \\
\text { Biomass } \\
\text { Proportion } \\
(\%)\end{array}$ & $\begin{array}{l}\text { Nitrogen } \\
\text { Use } \\
\text { Efficiency } \\
\left(\mathrm{kg} \mathrm{kg}^{-1}\right)\end{array}$ \\
\hline \multicolumn{6}{|l|}{ Fertilization $(\mathrm{F})$} \\
\hline Broadcast & $24.1 b^{1}$ & $19.4 \mathrm{~b}$ & $20.1 \mathrm{a}$ & $17.6 \mathrm{a}$ & $12.2 \mathrm{~b}$ \\
\hline Banded & $27.0 \mathrm{a}$ & $22.1 \mathrm{a}$ & $18.6 \mathrm{~b}$ & $13.8 \mathrm{~b}$ & $19.7 \mathrm{a}$ \\
\hline $\mathrm{LSD}_{\mathrm{F}}$ & 1.19 & 1.22 & 0.71 & 2.48 & 0.77 \\
\hline \multicolumn{6}{|l|}{ Intra-Row Spacing (IRS) } \\
\hline $15 \mathrm{~cm}$ & $21.8 \mathrm{c}$ & $17.4 \mathrm{~b}$ & $20.6 \mathrm{a}$ & $22.9 \mathrm{a}$ & $13.7 \mathrm{c}$ \\
\hline $11 \mathrm{~cm}$ & $26.2 \mathrm{~b}$ & $21.5 \mathrm{a}$ & $18.5 \mathrm{~b}$ & $14.2 \mathrm{~b}$ & $16.3 \mathrm{~b}$ \\
\hline $7 \mathrm{~cm}$ & $28.6 \mathrm{a}$ & $23.2 \mathrm{a}$ & $19.0 \mathrm{~b}$ & $10.1 \mathrm{c}$ & $17.9 \mathrm{a}$ \\
\hline LSD $_{\text {IRS }}$ & 1.50 & 1.34 & 1.02 & 3.56 & 0.86 \\
\hline \multicolumn{6}{|c|}{ Mechanical Weed Control (MWC) } \\
\hline Untreated (Control) & $21.1 \mathrm{c}$ & $16.5 \mathrm{a}$ & $22.0 \mathrm{a}$ & $30.1 \mathrm{a}$ & $13.1 \mathrm{c}$ \\
\hline One Treatment $(1 \times)$ & $26.3 \mathrm{~b}$ & $21.4 \mathrm{~b}$ & $18.8 \mathrm{~b}$ & $11.5 \mathrm{~b}$ & $16.4 \mathrm{~b}$ \\
\hline Two Treatments $(2 \times)$ & $29.2 \mathrm{a}$ & $24.2 \mathrm{a}$ & $17.3 \mathrm{c}$ & $5.6 \mathrm{c}$ & $18.3 \mathrm{a}$ \\
\hline LSD $_{\text {MWC }}$ & 1.96 & 1.57 & 1.00 & 3.79 & 1.22 \\
\hline
\end{tabular}

${ }^{1}$ Different lowercase letters in the same column indicate significant differences between means of each factor.

Total spinach biomass was influenced by both the factors of intra-row spacing and the number of mechanical weed control treatments as well. The same was observed regarding the relationship between commercial spinach biomass and intra-row spacing. Commercial spinach biomass was also strongly related to the number of mechanical weed control treatments that were applied. The second order polynomial regressions used to express the above-mentioned relationships are presented (Figure 3).
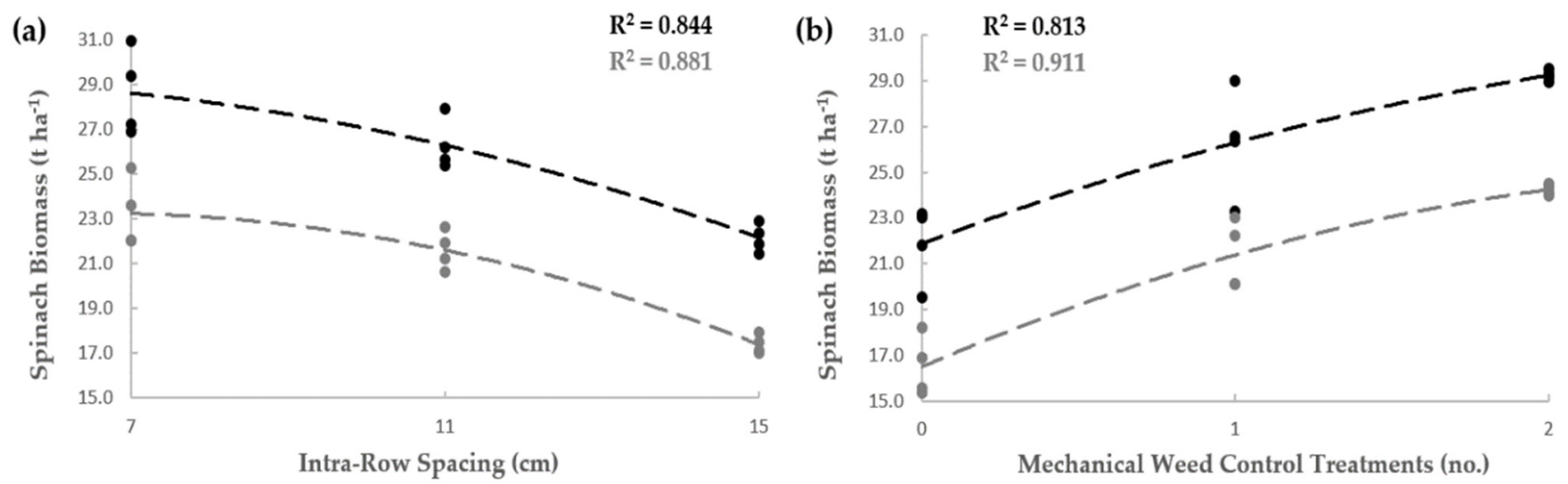

Figure 3. (a) Black: the relationship between total spinach biomass ( $\mathrm{t} \mathrm{ha}^{-1}$ ) and intra-row spacing (cm). Grey: the relationship between commercial spinach biomass $\left(\mathrm{t} \mathrm{ha}^{-1}\right)$ and intra-row spacing $(\mathrm{cm})$. (b) Black: the relationship between total spinach biomass $\left(\mathrm{t} \mathrm{ha}^{-1}\right)$ and the number of mechanical weed control treatments. Grey: the relationship between commercial spinach biomass $\left(\mathrm{tha}^{-1}\right)$ and the number of mechanical weed control treatments.

Total spinach biomass values were related to the different intra-row spacings according to the model: $T S B=28.3566+(0.432474 \times I R S)-\left(0.0563672 \times I R S^{2}\right)$ where TSB; total spinach biomass, IRS; intra-row spacing, $\mathrm{n}=12, p$-Value Model $\leq 0.001, \mathrm{R}^{2}=0.844$, root mean square error $(\mathrm{RMSE})=1.32479$, and mean absolute error $(\mathrm{MAE})=0.944132$. The following equation was used to establish cause-effect relationships between commercial spinach 
biomass and intra-row spacing: $C S B=19.9071+(1.0405 \times I R S)-\left(0.0805667 \times I R S^{2}\right)$ where CSB; commercial spinach biomass, IRS; intra-row spacing, $\mathrm{n}=12, p$-Value Model $\leq 0.001$, $\mathrm{R}^{2}=0.881$, root mean square error $(\mathrm{RMSE})=1.04555$, and mean absolute error $(\mathrm{MAE})=0.729403$ (Figure 3a). Crop biomass was by $17 \%$ in the subplots thinned to $11 \mathrm{~cm}$ than in the subplots thinned to $15 \mathrm{~cm}$ intra-row spacing. The corresponding increase in commercial biomass reached $21 \%$. Thinning the crop to obtain $7 \mathrm{~cm}$ distances between plants in the rows increased the fresh biomass of the crop by 9 and $24 \%$ in comparison to 11 and $15 \mathrm{~cm}$, respectively. Commercial biomass was by $8 \%$ higher under $7 \mathrm{~cm}$ than under $11 \mathrm{~cm}$ intra-row spacing. In addition, a threefold increase was recorded under the narrowest intra-row spacing $(7 \mathrm{~cm})$ compared to the widest intra-row spacing $(15 \mathrm{~cm})$.

The equation expressing total spinach biomass as a function of mechanical weed control was: $T S B=21.8782+(5.1345 \times M W C)-\left(0.729542 \times M W C^{2}\right)$ where TSB; total spinach biomass, $M W C$; mechanical weed control, $\mathrm{n}=12, p$-Value Model $\leq 0.001, \mathrm{R}^{2}=0.813$, root mean square error $(\mathrm{RMSE})=1.67268$, and mean absolute error $(\mathrm{MAE})=0.97166$. It was revealed that $81.3 \%$ of the variance in total spinach biomass was due to the different number of weed control treatments. The strong relationship between commercial spinach biomass and the number of mechanical weedings is expressed as: $C S B=16.4977+(5.89707$ $\times M W C)-\left(1.01323 \times M W C^{2}\right)$ where $C S B$; total spinach biomass, $M W C$; mechanical weed control, $\mathrm{n}=12, p$-Value Model $\leq 0.001, \mathrm{R}^{2}=0.911$, root mean square error $(\mathrm{RMSE})=1.15514$, and mean absolute error $(\mathrm{MAE})=0.821088$ (Figure $3 \mathrm{~b}$ ). Performing one weeding increased total and commercial spinach biomass by 20 and $23 \%$, respectively, in comparison to the untreated control. Doubling the number of mechanical treatments resulted in $9 \%$ higher crop biomass and 12\% higher commercial biomass. In addition, increases of 27 and 32\% were recorded for total and commercial spinach biomass, respectively, in sub-subplots receiving two mechanical operations than the values recorded in untreated plots.

As for other parameters, spinach waste proportion decreased in subplots with intrarow spacings of 7 and $11 \mathrm{~cm}$ compared to subplots with intra-row spacing of $15 \mathrm{~cm}$. The lowest values were observed in sub-subplots treated mechanically twice while the highest values corresponded to untreated sub-subplots. Intermediate values corresponded to one weeding. Similar observations were made regarding the proportion of fresh weed biomass in total spinach biomass. In particular, the lowest values of this parameter corresponded to $7 \mathrm{~cm}$ intra-row spacing and two mechanical weedings. Intermediate values corresponded to $11 \mathrm{~cm}$ intra-row spacing and one mechanical treatment. The lowest values corresponded to subplots with $15 \mathrm{~cm}$ intra-row spacing and sub-subplots where weeds were left uncontrolled. Following the differences observed in spinach biomass production, nitrogen use efficiency increased by $16 \%$ under $11 \mathrm{~cm}$ than under $15 \mathrm{~cm}$ intra-row spacing. Furthermore, the highest values of this index occurred under the narrowest intra-row spacing $(7 \mathrm{~cm})$. Concerning the effects of mechanical weed control on nitrogen use efficiency, performing a single operation increased its value by $20 \%$. Doubling the number of operations resulted in $9 \%$ higher nitrogen use efficiency compared to one single operation (Table 5).

\section{Discussion}

Combined with other experimental factors, banded fertilization reduced S. viridis biomass compared to broadcast fertilization. Blackshaw et al. [40] recorded a similar reduction in biomass of this species. It is, therefore, suggested that banding fertilizers at a depth of $10 \mathrm{~cm}$ under spinach rows (or at a depth of $7.5 \mathrm{~cm}$ depth under seed) is an effective method for the management of grass weeds with a shallow, fibrous rooting system such as S. viridis [40]. Different results were obtained for C. album. The little impact of banded fertilization on C. album can be attributed to the deep taproot of this broadleaf species, which allows nutrient uptake from deeper soil layers [40]. Although the effects of the fertilization method may depend on weed species, it was observed that banded fertilization reduced total weed biomass. Because most annual weeds germinate in the upper soil layers, broadcast fertilizer incorporation boosts their emergence and growth. In 
contrast, precise application of fertilizers placement at a certain depth reduces weed seed germination and also limits the access of germinated seedlings to the added nutrients [41].

Regarding the effects of spinach intra-row spacing on weed biomass, it was found that narrow intra-row spacings $(7$ and $11 \mathrm{~cm})$ resulted in significant reductions in S. viridis and C. album biomass and total weed biomass. An explanation might be that spinach establishment at narrow intra-row spacings accelerated crop canopy closure resulting in reductions of the light transmitted to the soil surface and the weeds growing beneath the crop canopy [27]. As a result, weed emergence and consequently weed biomass decreased with decreasing intra-row spacing, and these results are consistent with the corresponding findings of another recent study on spinach. In particular, De Cauwer et al. [9] also observed negative and strong linear regressions between weed biomass and intra-row spacing in two out of their three spinach cultivars studied. Reducing the distance between plants in the row is a common practice for weed suppression in a wide variety of minor crops and leafy vegetables [26]. Our results are also in agreement with recent studies conducted with poorly competitive legumes, whose growth rates are lower compared to spinach [28,29].

The above studies have also shown that increasing the number of mechanical weed control treatments is a recommended strategy to increase the efficacy of mechanical weed control. In the present study, such strong relationships were found as weed biomass decreased with the increasing number of weed control treatments. Two mechanical weed control treatments caused significant reductions in weed biomass compared to a single treatment. The explanation is that a single mechanical weed control treatment eliminated only the first flush of germinating weed seedlings; there were several weeds that escaped the treatment and continued to emerge and develop between crop rows. On the contrary, two mechanical weedings maximized the levels of weed control because the first treatment eliminated the first flush of early germinating weed seedlings, and the second operation controlled also the weed seedlings that escaped the first treatment [29]. Our results are in agreement with those of De Cauwer et al. [9] who found that the combination of pre-emergence and post-emergence mechanical weed control reduced weed biomass in spinach compared to a single treatment. These results are encouraging because optimizing mechanical weed control methods is a priority issue in spinach, where very few herbicides are approved for use [17]. Moreover, the performance of the cage weeder used for weed control between spinach rows in the present study was satisfactory. This is due to the fact that most weeds were between the 'white' or 'thread' (emergence) and 2-leaf growth stages at the time of treatment. Cage weeders work at very shallow depth and are, therefore, effective only on early germinating weed seedlings [33]. To control weeds at later growth stages between spinach rows, spring-tine harrows, and split-hoes are examples of the equipment that can be used [31,32]. In any case, research should continue and focus on both the efficacy and the selectivity of various mechanical weed control methods on spinach and other leafy vegetables.

Other findings of the current study were the cause-effect relationships established between weed and spinach biomass. The strong influence of weed competition on spinach productivity can be attributed to the low diversity in the weed community that infested this site. This situation is common in Greece, where the lack of crop rotation and sustainable farming practices has led to the development of low-diversity weed communities at several agricultural sites in the country. There are several examples from recent studies where strong and negative correlations between crop yield and weed biomass have been observed at such agricultural sites [29,42-44]. Weed diversity has recently been highlighted as an important factor determining the impact of weed interference on crop yield $[45,46]$. Metadata analysis by Storkey and Neve [13] showed that yield losses exceed $60 \%$ when the weed community is less diversified and consists of only five species. In contrast, yield losses are expected to be less than $30 \%$ when the weed community is diversified and consists of 20 weed species. The increased competitiveness of low-diversity weed communities can be attributed to the fact that they are usually dominated by species that have similar resource requirements to crops in a given agricultural area [47]. As a result, crops suffer 
from competition from weeds that compete strongly for the same or similar resources and are present in very high densities in the field $[13,48]$. Combinations of sustainable weed management practices should be implemented at such sites aiming to promote weed species diversity and restore weed flora composition. Several recent reports highlight the importance of weed diversity in mitigating crop yield losses because diverse weed communities tend to be less competitive to crops [48-51]. In addition, several studies have also indicated that increasing species diversity in weed communities is a measure to prevent the establishment of noxious invasive weeds on agricultural lands [16,52-54].

Concerning banded fertilization, it increased spinach yields compared to broadcast fertilization. This is attributed to the better access of spinach plants to nutrients due to the precise placement of fertilizer below crop rows. Our results agree with those of other researchers who found that banding fertilizers under crop rows resulted in higher crop productivity in another leafy vegetable, namely lettuce (Lactuca sativa L.) [36,37]. The same authors also found that banded fertilization increased crop yield at various C. album densities and periods of competition from this particular weed species. A similar trend was observed in the current research where although fertilization had no effect on C. album biomass, total and commercial spinach biomass increased in the main plots that received banded fertilization. In adition, lower fertilization inputs (approximately $45 \%$ ) and higher spinach yields resulted in improved nitrogen use efficiency for the crop. Our findings are consistent with other studies where alternative fertilization methods resulted in lower inputs, higher yields and improved nitrogen use efficiency for spinach [55].

As for the effects of the other factors on crop yield, strong relationships were observed either between intra-row spacing and spinach biomass or between the number of mechanical weed control treatments and spinach biomass. Spinach establishment at narrow intra-row spacing and two mechanical treatments resulted in lower weed biomass and consequently higher total and commercial biomass. These results are in line with those of other studies that also found a positive relationship between spinach stand density and crop yield, and between the number of weed control treatments and spinach biomass production [9]. These results are also in partial agreement with other studies where higher seeding rates and multiple mechanical weeding improved crop productivity compared to conventional agronomic practices [28,29].

\section{Conclusions}

Banded fertilization reduced weed biomass and fertilizer inputs and subsequently improved spinach yield and nitrogen use efficiency. Weed biomass decreased as spinach intra-row spacing decreased, and the number of mechanical weed control treatments increased. Reverse trends were observed in the total and commercial biomass of spinach. Both parameters increased when spinach intra-row spacing decreased, and the number of mechanical weed control treatments increased. Further research is needed to evaluate more cultural and non-chemical weed management practices in this crop where available herbicides are limited. In addition, competition from this low-diversity weed community affected the yield performance of spinach at a significant point. Our results validated that the loss of diversity in weed communities results in severe crop yield losses. Therefore, all sustainable weed management practices should be focused on increasing species diversity in the weed communities of such agricultural areas. As recently highlighted in several relevant studies, increasing the diversity of weed communities on agricultural land can be a measure to mitigate crop yield losses due to weed competition and prevent the establishment of noxious weed species.

Author Contributions: Conceptualization, I.G. and P.K.; methodology, I.G. and P.K.; software, N.A.; validation, I.G. and N.A.; formal analysis, I.G.; investigation, P.K.; resources, N.A.; data curation, I.G.; writing —original draft preparation, I.G.; writing—review and editing, P.K.; visualization, P.K. and N.A.; supervision, I.G.; project administration, P.K. All authors have read and agreed to the published version of the manuscript. 
Funding: This research received no external funding.

Institutional Review Board Statement: Not applicable.

Informed Consent Statement: Not applicable.

Data Availability Statement: The data presented in this study are available on request from the corresponding author.

Acknowledgments: We thank the anonymous reviewers for their valuable recommendations that have contributed to the improvement of this manuscript.

Conflicts of Interest: The authors declare no conflict of interest.

\section{References}

1. Morelock, T.E.; Correll, J.C. Spinach. In Vegetables I: Asteraceae, Brassicaceae, Chenopodicaceae, and Cucurbitaceae, 1st ed.; Prohens, J., Nuez, F., Eds.; Springer: New York, NY, USA, 2008; Volume 1, pp. 189-218. [CrossRef]

2. Food and Agriculture Organization of the United Nations. FAOSTAT. Available online: http://faostat.fao.org (accessed on 14 October 2021).

3. Roberts, J.L.; Moreau, R. Functional properties of spinach (Spinacia oleracea L.) phytochemicals and bioactives. Food Funct. 2016, 7, 3337-3353. [CrossRef]

4. Bunea, A.; Andjelkovic, M.; Socaciu, C.; Bobis, O.; Neacsu, M.; Verhé, R.; Van Camp, J. Total and individual carotenoids and phenolic acids content in fresh, refrigerated and processed spinach (Spinacia oleracea L.). Food Chem. 2008, 108, 649-656. [CrossRef]

5. Cocetta, G.; Baldassarre, V.; Spinardi, A.; Ferrante, A. Effect of cutting on ascorbic acid oxidation and recycling in fresh-cut baby spinach (Spinacia oleracea L.) leaves. Postharvest Biol. Technol. 2014, 88, 8-16. [CrossRef]

6. Gil, M.I.; Garrido, Y. Leafy vegetables: Fresh and fresh-cut mature spinach. In Controlled and Modified Atmospheres for Fresh and Fresh-Cut Produce; Gil, M.I., Beaudry, R., Eds.; Academic Press: Cambridge, MA, USA, 2020; pp. 551-555. [CrossRef]

7. Ribera, A.; Bai, Y.; Wolters, A.M.A.; van Treuren, R.; Kik, C. A review on the genetic resources, domestication and breeding history of spinach (Spinacia oleracea L.). Euphytica 2020, 216, 48. [CrossRef]

8. Van der Vossen, H.A.M. Spinacia oleracea. In Plant Resources of Tropical Africa 2: Vegetables; Grubben, G.J.H., Denton, O.A., Eds.; Backhuys Publishers: Wageningen, The Netherlands, 2004; pp. 513-515. Available online: https://edepot.wur.nl/417517 (accessed on 14 October 2021).

9. De Cauwer, B.; Delanote, L.; Devos, M.; De Ryck, S.; Reheul, D. Optimisation of weed control in organic processing spinach (Spinacia oleracea L.): Impacts of cultivar, seeding rate, plant spacing and integrated weed management strategy. Agronomy 2021, 11, 53. [CrossRef]

10. Lati, R.N.; Rachuy, J.S.; Fennimore, S.A. Weed management in fresh market spinach (Spinacia oleracea) with phenmedipham and cycloate. Weed Technol. 2015, 29, 101-107. [CrossRef]

11. Wallace, R.W.; Phillips, A.L.; Hodges, J.C. Processing Spinach Response to selected herbicides for weed control, crop injury, and yield. Weed Technol. 2007, 21, 714-718. [CrossRef]

12. Légére, A.; Stevenson, F.C.; Benoit, D.L. Diversity and assembly of weed communities: Contrasting responses across cropping systems. Weed Res. 2005, 45, 303-315. [CrossRef]

13. Storkey, J.; Neve, P. What good is weed diversity? Weed Res. 2018, 58, 239-243. [CrossRef]

14. Travlos, I.S.; Cheimona, N.; Roussis, I.; Bilalis, D.J. Weed-species abundance and diversity indices in relation to tillage systems and fertilization. Front. Environ. Sci. 2018, 6, 11. [CrossRef]

15. Neve, P.; Busi, R.; Renton, M.; Vila-Aiub, M.M. Expanding the eco-evolutionary context of herbicide resistance research. Pest Manag. Sci. 2014, 70, 1385-1393. [CrossRef]

16. Perrino, E.V.; Calabrese, G. Endangered segetal species in southern Italy: Distribution, conservation status, trends, actions and ethnobotanical notes. Genet. Resour. Crop Evol. 2018, 65, 2107-2134. [CrossRef]

17. Wallace, R.W.; Miller, T.W.; Masabni, J.G. Sustainable weed control in vegetables. In Weed Control, 1st ed.; Korres, N.E., Burgos, N.R., Duke, S.O., Eds.; CRC Press: Boca Raton, FL, USA, 2018; pp. 404-424. Available online: https: / / www.taylorfrancis.com/chapters/edit/10.1201/9781315155913-21/sustainable-weed-control-vegetables-russell-wallacetimothy-miller-joseph-masabni (accessed on 13 November 2021).

18. Foppa Pedretti, E.; Boakye-Yiadom, K.A.; Valentini, E.; Ilari, A.; Duca, D. Life Cycle Assessment of spinach produced in Central and Southern Italy. Sustainability 2021, 13, 10001. [CrossRef]

19. Grigg, S. Spinach-A Global Expedition to Understand the Prevalence of Damping off and Practical Management Techniques. 2015. Available online: https://www.issinstitute.org.au/wp-content/uploads/2015/04/Report-Grigg-FINAL-LowRes.pdf (accessed on 14 November 2021).

20. Savvas, D.; Akoumianakis, K.; Karapanos, I.; Kontopoulou, C.K.; Ntatsi, G.; Liontakis, A.; Sintori, A.; Ropokis, A.; Akoumianakis, A. Recharging Greek Youth to Revitalize the Agriculture and Food Sector of the Greek Economy. Final Report-Sectoral Study 5. Vegetables: Open-Field and Greenhouse Production. 2015. Available online: https://www.generationag.org/assets/site/public/ nodes/1019/1055-Vegetables_Open-Field_and_Greenhouse_Production.pdf (accessed on 14 November 2021). 
21. Commission Implementing Regulation (EU) 2021/1449 of 3 September 2021 Amending Implementing Regulation (EU) No 540/2011 as Regards the Extension of the Approval Periods of the Active Substances 2-Phenylphenol (Including its Salts Such as the Sodium Salt), 8-Hydroxyquinoline, Amidosulfuron, Bifenox, Chlormequat, Chlorotoluron, Clofentezine, Clomazone, Cypermethrin, Daminozide, Deltamethrin, Dicamba, Difenoconazole, Diflufenican, Dimethachlor, Etofenprox, Fenoxaprop-P, Fenpropidin, Fludioxonil, Flufenacet, Fosthiazate, Indoxacarb, Lenacil, MCPA, MCPB, Nicosulfuron, Paraffin Oils, Paraffin Oil, Penconazole, Picloram, Propaquizafop, Prosulfocarb, Quizalofop-P-Ethyl, Quizalofop-P-Tefuryl, Sulphur, Tetraconazole, Tri-Allate, Triflusulfuron and Tritosulfuron (Text with EEA Relevance). Available online: https://eur-lex.europa.eu/legalcontent/EN/TXT/PDF/?uri=CELEX:32021R1449\&from=EN (accessed on 14 November 2021).

22. Lewis, K.A.; Tzilivakis, J.; Warner, D.; Green, A. An international database for pesticide risk assessments and management. Hum. Ecol. Risk Assess. 2016, 22, 1050-1064. [CrossRef]

23. Lati, R.N.; Mou, B.; Rachuy, J.S.; Fennimore, S.A. Light intensity is a main factor affecting fresh market spinach tolerance for phenmedipham. Weed Sci. 2016, 64, 146-153. [CrossRef]

24. Lati, R.N.; Mou, B.; Rachuy, J.S.; Fennimore, S.A. Evaluation of cycloate followed by evening two-leaf-stage phenmedipham application in fresh market spinach. Weed Technol. 2016, 30, 464-471. [CrossRef]

25. Heap, I. The International Herbicide-Resistant Weed Database. Available online: www.weedscience.org (accessed on 16 November 2021).

26. Pannacci, E.; Lattanzi, B.; Tei, F. Non-chemical weed management strategies in minor crops: A review. Crop Prot. 2017, 96, 44-58. [CrossRef]

27. Korres, N.E. Agronomic weed control: A trustworthy approach for sustainable weed management. In Non-Chemical Weed Control; Jabar, K., Chauhan, B.S., Eds.; Academic Press: Cambridge, MA, USA, 2018; pp. 97-114. [CrossRef]

28. Alba, O.S.; Syrovy, L.D.; Duddu, H.S.; Shirtliffe, S.J. Increased seeding rate and multiple methods of mechanical weed control reduce weed biomass in a poorly competitive organic crop. Field Crops Res. 2020, 245, 107648. [CrossRef]

29. Kanatas, P.J.; Gazoulis, I. The integration of increased seeding rates, mechanical weed control and herbicide application for weed management in chickpea (Cicer arietinum L.). Phytoparasitica 2021, in press. [CrossRef]

30. Benaragama, D.; Shirtliffe, S.J. Integrating cultural and mechanical methods for additive weed control in organic systems. Agron. J. 2013, 105, 1728-1734. [CrossRef]

31. Peruzzi, A.; Ginanni, M.; Raffaelli, M.; Borelli, M. Physical weed control in organic spinach production. In Proceedings of the 6th EWRS Workshop on Physical and Cultural Weed Control, Lillehammer, Norway, 8-10 March 2004; Cloutier, D.C., Ascard, J., Eds.; pp. 15-23. Available online: https: / / citeseerx.ist.psu.edu/viewdoc/download?doi=10.1.1.622.7735\&rep=rep1\&type=pdf\# page $=22$ (accessed on 9 October 2021).

32. Tei, F.; Stagnari, F.; Granier, A. Preliminary results on physical weed control in processing spinach. In Proceedings of the 5th EWRS Workshop on Physical and Cultural Weed Control, Pisa, Italy, 11-13 March 2002; Cloutier, D.C., Ed.; pp. 164-171. Available online: https: / / citeseerx.ist.psu.edu/viewdoc/download?doi=10.1.1.113.5384\&rep=rep1\&type=pdf\#page=171 (accessed on 9 October 2021).

33. Cloutier, D.C.; Van der Weide, R.Y.; Peruzzi, A.; Leblanc, M.L. Mechanical weed management. In Nonchemical Weed Management: Principles, Concepts and Technology; Upadhyaya, M.K., Blackshaw, R.E., Eds.; CAB International: Wallingford, UK, 2007; pp. 111-134. Available online: https: / / edepot.wur.nl/116036 (accessed on 10 October 2021).

34. DiTomaso, J.M. Approaches for improving crop competitiveness through the manipulation of fertilization strategies. Weed Sci. 1995, 43, 491-497. [CrossRef]

35. Little, N.G.; DiTommaso, A.; Westbrook, A.S.; Ketterings, Q.M.; Mohler, C.L. Effects of fertility amendments on weed growth and weed-crop competition: A review. Weed Sci. 2021, 69, 132-146. [CrossRef]

36. Santos, B.M.; Dusky, J.A.; Stall, W.M.; Gilreath, J.P. Effects of phosphorus fertilization on common lambsquarters (Chenopodium album) duration of interference in lettuce (Lactuca sativa). Weed Technol. 2004, 18, 152-156. [CrossRef]

37. Santos, B.M.; Dusky, J.A.; Stall, W.M.; Gilreath, J.P. Influence of common lambsquarters (Chenopodium album) densities and phosphorus fertilization on lettuce. Crop Prot. 2004, 23, 173-176. [CrossRef]

38. Su, W.; Liu, B.; Liu, X.; Li, X.; Ren, T.; Cong, R.; Lu, J. Effect of depth of fertilizer banded-placement on growth, nutrient uptake and yield of oilseed rape (Brassica napus L.). Eur. J. Agron. 2015, 62, 38-45. [CrossRef]

39. Grouner. Grouner-Dischargers of Artificial Rain, Thessaloniki, Greece. 1938. Available online: http:/ /www.grouner.gr/en/ products.php?cat=8 (accessed on 15 November 2021).

40. Blackshaw, R.E.; Molnar, L.J.; Janzen, H.H. Nitrogen fertilizer timing and application method affect weed growth and competition with spring wheat. Weed Sci. 2004, 52, 614-622. [CrossRef]

41. Kaur, S.; Kaur, R.; Chauhan, B.S. Understanding crop-weed-fertilizer-water interactions and their implications for weed management in agricultural systems. Crop Prot. 2018, 103, 65-72. [CrossRef]

42. Kanatas, P.; Antonopoulos, N.; Gazoulis, I.; Travlos, I.S. Screening glyphosate-alternative weed control options in important perennial crops. Weed Sci. 2021, 69, 704-718. [CrossRef]

43. Kanatas, P.; Gazoulis, I.; Travlos, I. Irrigation timing as a practice of effective weed management in established alfalfa (Medicago sativa L.) crop. Agronomy 2021, 11, 550. [CrossRef]

44. Travlos, I.; Tsekoura, A.; Antonopoulos, N.; Kanatas, P.; Gazoulis, I. Novel sensor-based method (quick test) for the in-season rapid evaluation of herbicide efficacy under real field conditions in durum wheat. Weed Sci. 2021, 69, 147-160. [CrossRef] 
45. Moss, S.R.; Storkey, J.; Cussans, J.W.; Perryman, S.A.M.; Hewitt, M.V. The Broadbalk long-term experiment at Rothamsted: What has it told us about weeds? Weed Sci. 2004, 52, 864-873. [CrossRef]

46. Pollnac, F.W.; Maxwell, B.D.; Menalled, F.D. Weed community characteristics and crop performance: A neighbourhood approach. Weed Res. 2009, 49, 242-250. [CrossRef]

47. Borgy, B.; Gaba, S.; Petit, S.; Reboud, X. Non-random distribution of weed species abundance in arable fields. Weed Res. 2012, 52, 383-389. [CrossRef]

48. Smith, R.G.; Mortensen, D.A.; Ryan, M.R. A new hypothesis for the functional role of diversity in mediating resource pools and weed-crop competition in agroecosystems. Weed Res. 2010, 50, 37-48. [CrossRef]

49. Adeux, G.; Vieren, E.; Carlesi, S.; Bàrberi, P.; Munier-Jolain, N.; Cordeau, S. Mitigating crop yield losses through weed diversity. Nat. Sustain. 2019, 2, 1018-1026. [CrossRef]

50. Cierjacks, A.; Pommeranz, M.; Schulz, K.; Almeida-Cortez, J. Is crop yield related to weed species diversity and biomass in coconut and banana fields of northeastern Brazil? Agric. Ecosyst. Environ. 2016, 220, 175-183. [CrossRef]

51. Ferrero, R.; Lima, M.; Davis, A.S.; Gonzalez-Andujar, J.L. Weed diversity affects soybean and maize yield in a long term experiment in Michigan, USA. Front. Plant Sci. 2017, 8, 236. [CrossRef]

52. Harker, K.N.; Clayton, G.W.; O’Donovan, J.T. Reducing agroecosystem vulnerability to weed invasion. In Invasive Plants: Ecological and Agricultural Aspects; Inderjit, S., Ed.; Birkhäuser: Basel, Switzerland, 2005; pp. 195-207.

53. Tracy, B.F.; Renne, I.J.; Gerrish, J.; Sanderson, M.A. Effects of plant diversity on invasion of weed species in experimental pasture communities. Basic Appl. Ecol. 2004, 5, 543-550. [CrossRef]

54. $\mathrm{Wu}, \mathrm{H}$.; Carrillo, J.; Ding, J. Invasion by alligator weed, Alternanthera philoxeroides, is associated with decreased species diversity across the latitudinal gradient in China. J. Plant Ecol. 2016, 9, 311-319. [CrossRef]

55. Canali, S.; Diacono, M.; Ciaccia, C.; Masetti, O.; Tittarelli, F.; Montemurro, F. Alternative strategies for nitrogen fertilization of overwinter processing spinach (Spinacia oleracea L.) in Southern Italy. Eur. J. Agron. 2014, 54, 47-53. [CrossRef] 